УДК 621.371(260).029.65

\title{
ВЛИЯНИЕ ДВУКРАТНОГО ВЗАИМОДЕЙСТВИЯ ПРИ МНОГОЛУЧЕВОМ РАСПРОСТРАНЕНИИ ПОД МАЛЫМИ УГЛАМИ СКОЛЬЖЕНИЯ
}

\author{
ЛОГВИНОВ Ю. Ф., РАЗСКАЗОВСКИЙ В. Б. \\ Институт радиофизики и электроники Национальной Академии наук Украинь,, \\ Украина, Харьков, 61085, ул. Проскуры 12
}

\begin{abstract}
Аннотация. При слабом ветровом волнении неровности поверхности впадин между гребнями морских волн оказываются вне зоны глубокого затенения по отношению к корреспондирующим пунктам и необходимо оценить их роль в формировании поля в точке приема. Анализ показал, что в таких условиях может иметь место многократное взаимодействие облучающего поля с неровностями подстилающей поверхности. Вследствие значительного уменьшения при каждом акте переизлучения амплитуды вторичной волны относительно первичной анализ ограничен учетом двукратного взаимодействия. Оценить его влияние в работе предлагается методом сравнения характеристик принятого сигнала, полученных при учете двукратного взаимодействия и без него.

Характеристики получены путем моделирования процессов распространения электромагнитного поля при слабом ветровом волнении в рамках приближения Кирхгофа с использованием принципа вторичных источников Гюйгенса
\end{abstract}

Ключевые слова: миллиметровая радиоволна; морская поверхность; предельно малые углы скольжения; слабое волнение поверхности; двукратное взаимодействие

В теоретических работах по распространению радиоволн над неровной поверхностью, когда горизонтальные размеры неровностей существенно превышают длину радиоволны, используется предположение об однократном взаимодействии каждого луча облучающей волны с поверхностью [1-3]. Предполагается также, что это взаимодействие происходит в окрестностях точки встречи луча с поверхностью.

В [4-12] показано, что такое допущение при определенных условиях применимо к случаю скользящего распространения миллиметровых и сантиметровых радиоволн над морской поверхностью с ветровыми волнами. Это обусловлено тем, что при скоростях ветра над поверхностью моря свыше некоторого критического значения при малых углах скольжения (порядка единиц миллирадиан) освещенными остаются только вершины морских волн, а впадины между ними оказываются в зоне глубокой тени по отношению к излучателю и приемнику.

В предположении, что поверхность впадины облучается полем, являющимся результатом дифракции первичной плоской электромагнитной волны на полуплоскости, граница которой совпадает с гребнем волны, создающим тень, в [4] получено условие

$$
U_{10}>\frac{37,5 \sqrt{\lambda}}{1-75 \psi_{\mathrm{c \kappa}}},
$$

при выполнении которого поле на дне впадины на 10 дБ ослаблено по сравнению с присутствующим выше границы тени. Здесь $U_{10}-$ скорость ветра на высоте 10 м над поверхностью моря $[\mathrm{m} / \mathrm{c}] ; \lambda$ - длина волны $[\mathrm{M}] ; \psi_{\text {ск }}-$ угол 